\begin{tabular}{|c|c|c|}
\hline & $\begin{array}{l}\text { International Journal of Current Research in } \\
\text { Biosciences and Plant Biology }\end{array}$ & $=$ \\
\hline & Volume 7 • Number 1 (January-2020) • ISSN: 2349-8080 (Online) & $\because 0$ \\
\hline $\begin{array}{l}\text { EXCELLEN } 1 \\
\text { PUBLISHERS }\end{array}$ & Journal homepage: $\underline{w w w . i j c r b p . c o m}$ & \\
\hline
\end{tabular}

\title{
Effect of essential oil and powders of Tithonia diversifolia on the growth parameters and yield of rice in the field
}

\section{Dongmo Nanfack Albert* ${ }^{*}$, Nguefack Julienne, Fouelefack François Romain², Dakolé Daboy Charles', Kuate Tueguem William Norbert4, Nkengfack Augustin Ephraïm ${ }^{3}$ and Dongmo Lekagne Joseph Blaise'}

\author{
${ }^{1}$ Department of Biochemistry, University of Yaoundé 1, Cameroon \\ ${ }^{2}$ Department of Biological Sciences, University of Maroua, Cameroon \\ 3Department of Organic Chemistry, University of Yaoundé 1, Cameroon \\ 4Department of Plant Biology, Laboratory of Biotechnology, Plant pathology and Plant Protection, \\ University of Yaoundé 1, Cameroon \\ *Corresponding author; e-mail: adongmonanfack@yahoo.com
}

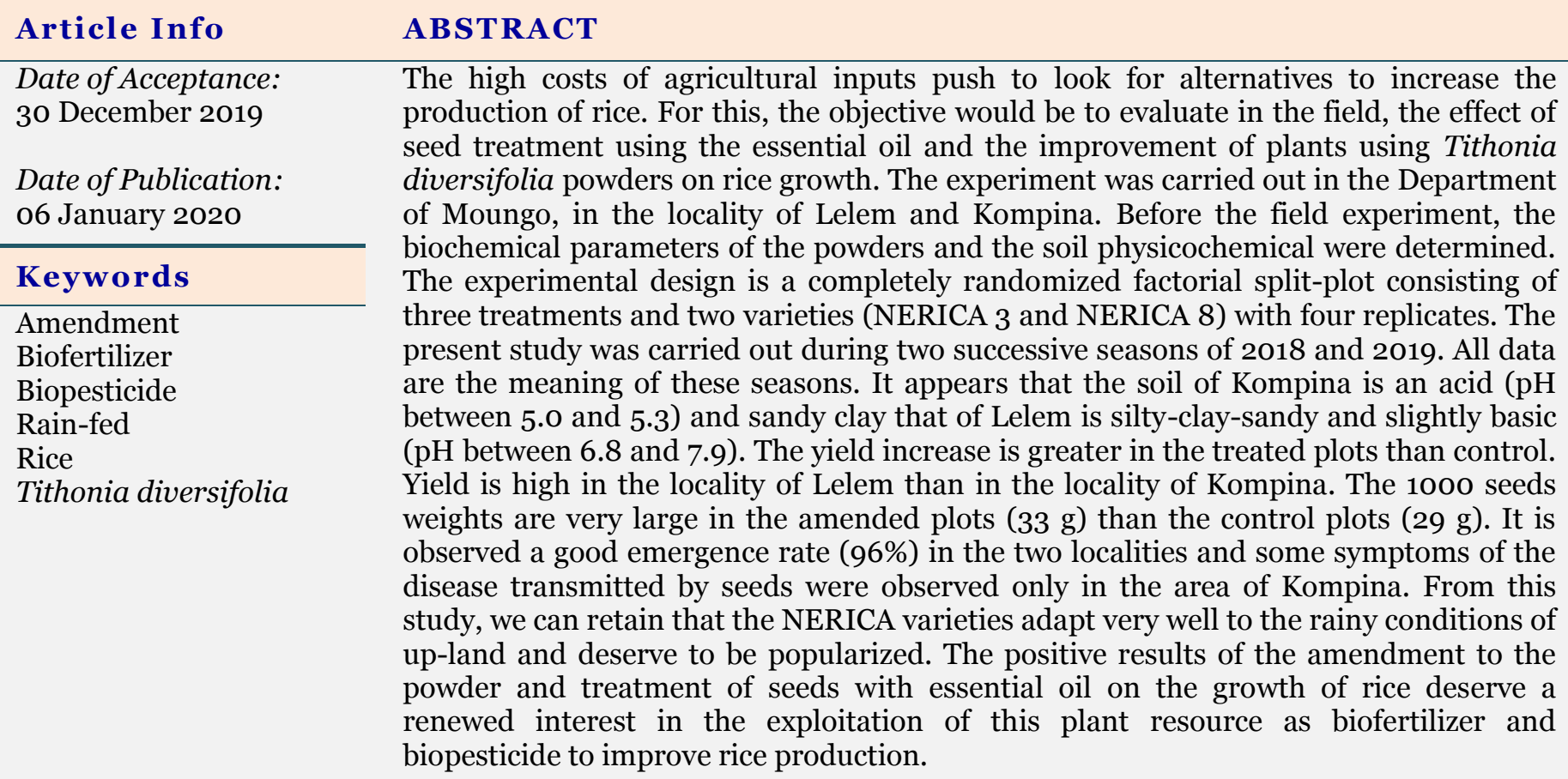

\section{Introduction}

In a rapidly changing socio-economic context in
Cameroon, rice production is evolving very slowly. In fact, paddy rice production in Cameroon increased from 181,818 tonnes in 2012 to 359,320 
in 2016 (MINADER/DESA, 2017); but, with the social and economic crises in the North-West, South-West, North, and East since 2016, this production is almost reduced to 332,534 tonnes in 2018; on the contrary, the consumption of white rice increased from 500,000 tonnes in 2015 to about 700,000 tonnes in 2018 (Faostat, 2019). Thus, Cameroon depend on imports to meet the needs of this foodstuff. Rice is cultivated mainly under irrigated system, in all agro-ecological zones of Cameroon mainly in; the Sudano-Sahelian zone in the Far North of the country (Yagoua, Kousseri, Lagdo), the humid tropical zone in the Centre- EstSouth and the highlands zone in the West (Ndop, Tonga, Santchou) (MINADER/DESA, 2017).

In 1994, scientists of the African Rice Center have successfully obtained a new variety rice type called NERICA (New Rice for Africa) which is promising for countries in Sub Saharan Africa (Sarla and Mallikarjuna, 2005); sub-types of NERICA easily adapted under irrigated and in rainfed upland systems and are being tested in many African counties including Cameroon. Several constraints including the difficulty of accessing to agricultural inputs (fertilizers and pesticides), the insufficiency of healthy rice seeds, and diseases, reduce rice production in Cameroon (Nguefack et al., 2005). These constraints could cause more or less severe damage ranging from 6 to more than $90 \%$ of production losses (Agarwal et al., 1989; Kohls and Percich, 1987), Synthetic chemicals used in the management of rice are sometimes not available, costly for poor farmers and can negatively affect ecosystems (Kagale et al., 2004; Harish et al., 2008).

Plant and plant extracts are amongst other, sources of biological agrochemicals that can be used as biofertilizers as well as bio-pesticides to replace their synthetic counterpart in the plant management (Guilter, 1998; Bengyella et al., 2011); regarding to this, Tithonia diversifolia has been used as biofertilizer and some of its extracts has exhibited antimicrobial activities (Kaho et al., 2011; Linthoingambi et al., 2013); thus, this work, consist to assess the effect of seed treatment with essential oils and soil amendment with $T$. diversifolia powder, under field conditions on the growth parameters (emergence, vigor, tillering, disease index and the production yield) of two NERICA rice varieties; N3 and N8.

\section{Materials and methods}

\section{Rice seed samples}

Two cultivars of NERICA rice seeds (NERICA 8 and NERICA 3) were obtained from the Institute of Agricultural Research for Development (IRAD). These cultivars were collected and selected according to the protocol described by Fouelefack et al. (2018).

\section{Plant material and preparation of powders}

Plant material was constituted of leaves of Tithonia diversifolia harvested in March 2017 for the first season of rice culture (March-June) and in June 2019, in Yaoundé Cameroon for the second season of rice culture (September-November). About 300 $\mathrm{kg}$ of the harvested leaves were placed on a

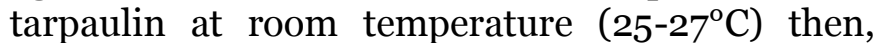
stirred regularly for about three weeks until complete shade dry. The powders were obtained after grinding the dry material, then weighed and stored at $25{ }^{\circ} \mathrm{C}$ for later use.

\section{Phytochemical screening: qualitative determination}

Standard methods of qualitative analysis described by Harbone (1998) and Edeoga et al. (2005) were used for the determination of secondary metabolites in plant powder.

\section{Preparation of essential oil}

The essential oil was obtained from fresh leaves of $T$. diversifolia by the hydrodistillation method for about 4 hours using the Clevenger apparatus: $T$. diversifolia leaves in water are heated at about 100 ${ }^{\circ} \mathrm{C}$; the essential oil carried by water vapours is condensed in the settling column of the Clevenger apparatus, collected, dried through anhydrous sodium sulphate, weighed and stored at $4{ }^{\circ} \mathrm{C}$ for later use

\section{Chemical analyses of powders from leaves of $T$. diversifolia and soil}

Samples: The requested analyses were carried out on five (05) samples of soils (1000 g soil samples) taken at different locations of the experimental sites according to the protocol described by 
Pauwels et al. (1992). And two (02) samples sources of organic matter (OM), in particular, $T$. diversifolia powder (500 g of plant powder). The samples were taken by the applicant at an experimental site before cultivation, to determine the level of nutrients in the soil and the sources of OM. The samples were packaged and brought to URASCE on 04/15/2019, under the conditions specified by the unit (Pauwels et al., 1992).

Analyses: The analyses carried out in the soil surface samples $(0-20 \mathrm{~cm})$ mainly included the contents of sand, clay and silt, the $\mathrm{pH}$ in aqueous $\left(\mathrm{pH}-\mathrm{H}_{2} \mathrm{O}\right)$ and saline $(\mathrm{pH} \mathrm{KCl})$, the content in organic carbon ( $\mathrm{CO}$ ), the total nitrogen content (Ntot), the content of exchangeable bases $(\mathrm{Ca}, \mathrm{Mg}$, $\mathrm{K}$ and $\mathrm{Na}$ ), the exchangeable acidity (AE), the cation exchange capacity (CEC), the rate base saturation (V), the effective cation exchange capacity (CECE) and the assimilable phosphorus content (P Bray II). However, the analyses carried out in the OM source samples consisted of $\mathrm{pH}, \mathrm{CO}$, OM, Ntot, $\mathrm{N}-\mathrm{NO}_{3}^{-}, \mathrm{N}-\mathrm{NH}_{4}{ }^{+}$, total phosphorus (Ptot), $\mathrm{Ca}, \mathrm{Mg}, \mathrm{K}, \mathrm{Na}, \mathrm{Fe}$, and $\mathrm{S}$.

Methodology: The physicochemical and chemical parameters contained in the soils were determined according to the methods in force at URASCE, recommended by Pauwels et al. (1992) and complying with ISO, AFNOR NF, and EN standards. It is :

Total nitrogen: mineralization by the acid attack of $2 \mathrm{~g}$ of sample, distillation by steam entrainment and determination with sulfuric acid (Kjeldahl method, standard NF ISO 11261);

Assimilable phosphorus; blue ammonium molybdenum colorimetry after

The methodology: The physicochemical and chemical parameters contained in the soils were determined according to the methods in force at URASCE, recommended by Pauwels et al. (1992) and complying with ISO, AFNOR NF, and EN standards. It is :

Assimilable phosphorus; colorimetry with ammonium molybdenum blue after extraction with an acid solution $(\mathrm{HCl}+$ $\mathrm{NH}_{4} \mathrm{~F}$ ) of Bray II of $2.5 \mathrm{~g}$ of the sample and reading at the wavelength $665 \mathrm{~nm}$ (standard NF X 31-130);
Potassium and sodium: flame emission spectrometry by direct reading in the ammonium acetate extract at $\mathrm{pH} 7$ of the sample ((AFNOR NF T 90 - 019 standard);

CEC: by extraction of exchangeable cations, washing with alcohol, replacement of $\mathrm{NH}_{4}+$ ions with $\mathrm{K}+$ ions of $\mathrm{KCl} 1 \mathrm{~N}$, distillation by steam entrainment and dosing with $0.01 \mathrm{~N}$ sulfuric acids (standard NF EN ISO 23470);

Calcium and magnesium; complexometric and titrimetric method of an ammonium acetate extract at $\mathrm{pH} 7$ of the sample. (AFNOR NF U 44 - 146 standard);

The grain size (sand, clay, and silt); Robinson Kôhn pipette method after the destruction of organic matter by hydrogen peroxide and iron oxides as well as carbonates with hydrochloric acid (standard NFX 31 - 107);

Organic carbon; oxidation of $0.3 \mathrm{~g}$ of sample with potassium dichromate $\left(\mathrm{K}_{2} \mathrm{Cr}_{2} \mathrm{O}_{7}\right)$ and assay in return of the remaining dichromate with ferrous sulfate heptahydrate $\left(\mathrm{FeSO}_{4}, 7 \mathrm{H}_{2} \mathrm{O}\right)$, (standard AFNOR NFU 44 - 051);

$\mathrm{pH}$; potentiometry using a "Hanna Instruments" brand $\mathrm{pH}$ meter in the aqueous extract of ratio $1 ; 2.5$ (ISO 10390 standard).

\section{Rice seed treatments}

The rice seeds were treated with an emulsion of 3 $\%$ essential oil diluted in $1 \%$ agar: They were coated with essential oil emulsion at the rate of 100 $\mu \mathrm{l} / \mathrm{g}$ of seed in a tightly closed box for $15 \mathrm{~min}$; then spread on sterile blotting paper and dried at $25{ }^{\circ} \mathrm{C}$ for 24 hours before sowing.

\section{Study sites and experimental design}

The field experiments were conducted in two sites: The first site is located at Lelem Mangwete, in the district of Melong (latitude $5^{\circ} 15^{\prime} \mathrm{N}$, longitude $9^{\circ} 97^{\prime}$ $\mathrm{E}$ and altitude 737.00m-2417.98 m), Department of Moungo-North, bordering the Santchou (Fig. 1). The second site is Kompina, in the municipality of Dibombari (altitude $3^{\circ} 59^{\prime}-4^{\circ} 80^{\prime} \mathrm{N}$, longitude and $9^{\circ} \quad 45^{-} 9^{\circ} 83^{\prime} \mathrm{E}$ and altitude $02 \mathrm{~m}-92 \mathrm{~m}$ ), Department of South-Moungo bordering Bonabéri (Fig. 2). The climate of both localities is equatorial of Guinean type and the precipitations ranged between 2350-2402 mm/year; the soils are black and predominantly clay-lateritic and ferralitic (Moudingo, 2007). 
The field trials were carried out from March to July 2018; the experimental land was cleaned and ploughed; the trial was laid out in a randomized complete split-plot design (Sehgal, 2012; Dagnelie, 2012) with four repetitions, in elementary plot size of $2.5 \times 3 \mathrm{~m}$ (area of $7.5 \mathrm{~m}^{2}$ ). The combination of 2 rice varieties and 3 treatments gave a total of $6(3 \mathrm{x}$ 2) 6 elementary plots per block (Fig. 3). Five (5) seeds per hill were directly sown, with $20 \mathrm{~cm}$ spacing between hills in each row and $20 \mathrm{~cm}$ spacing between rows. Weeds were removed manually at $20^{\text {th }}$ and $45^{t^{\mathrm{h}}}$ days after sowing. Fertilizers were applied around each hill 3 times at the $21^{\text {st }} ; 45^{\text {th }}$ and $70^{\text {th }}$ day; at the rate of $20 \mathrm{~g} /$ hill for $T$. diversifolia powder and $4 \mathrm{~g} / \mathrm{hill}$ for chemical fertilizer 20.10.10 NPK. Traps and nets were used to fight against rodents and birds.

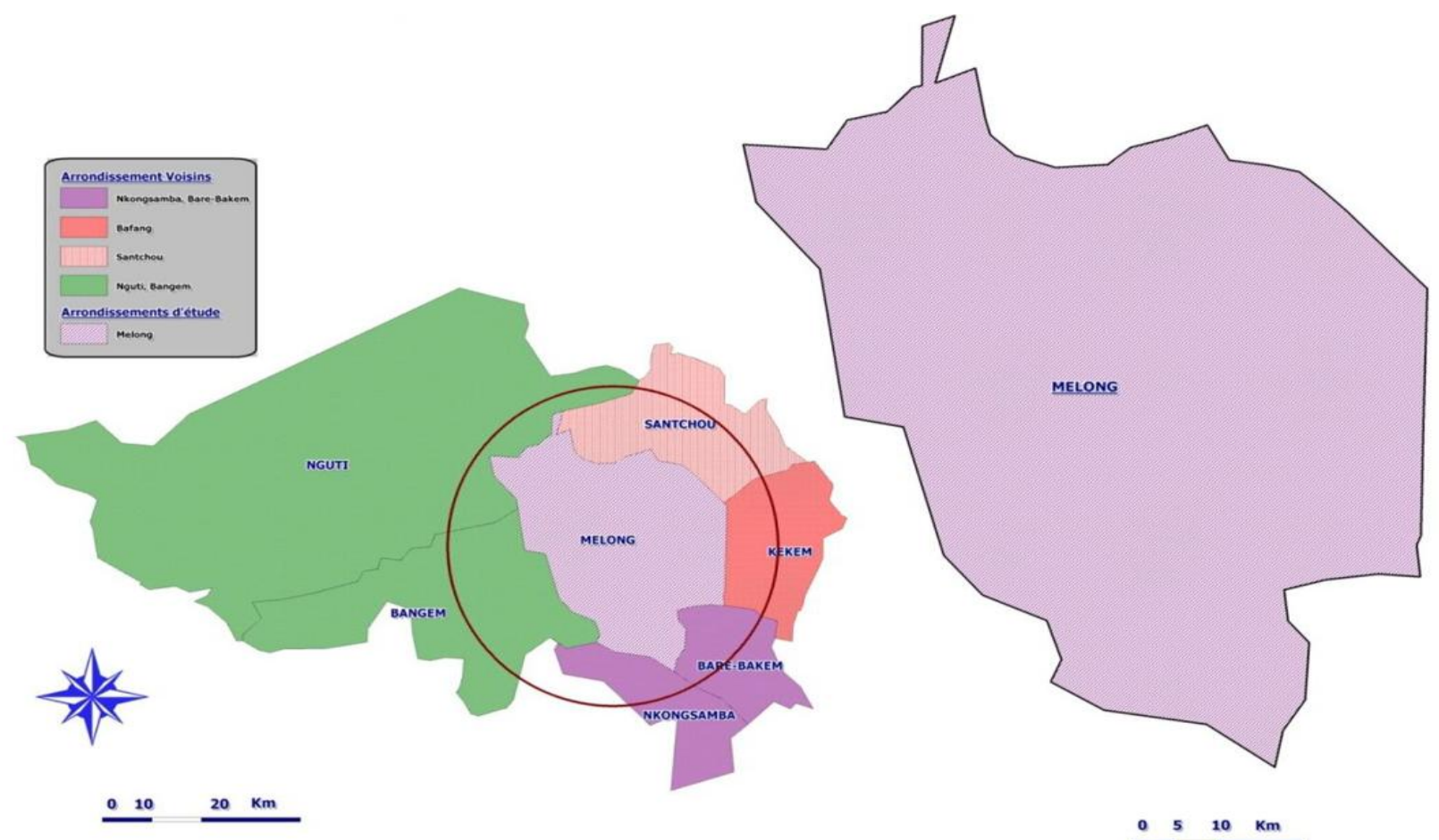

Fig. 1: Location map of the Municipality of Melong (AGRISTAT-MINADER $\overline{2010} \overline{\text { data)}}$.
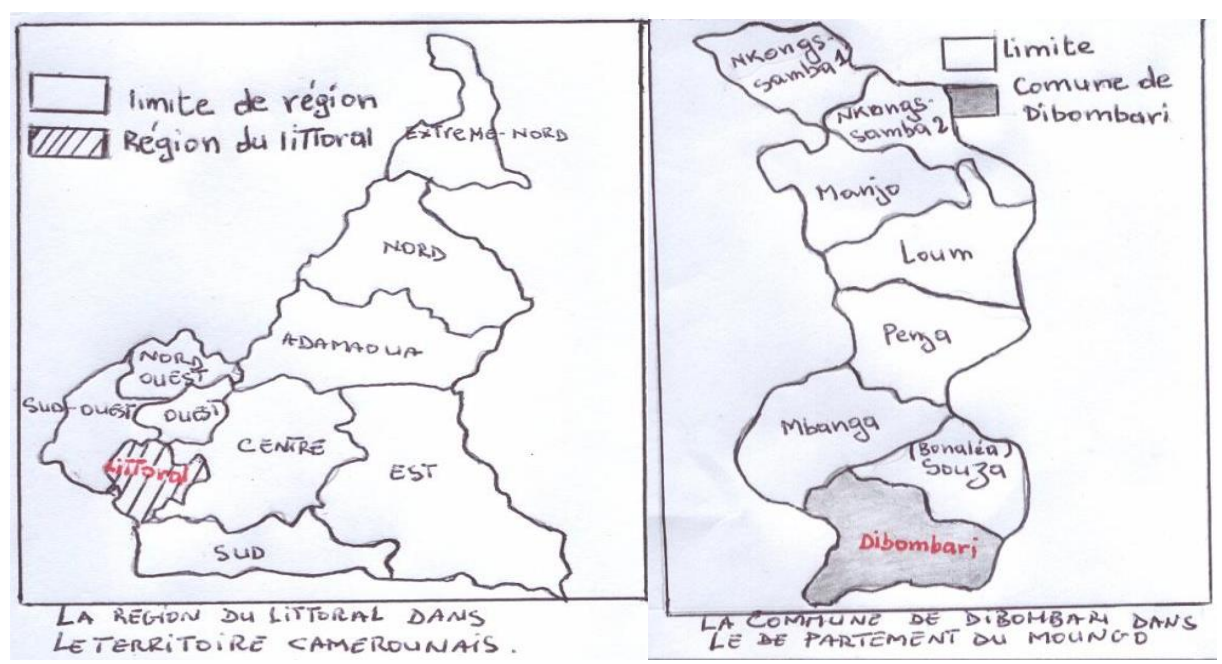

Fig. 2: Location map of the Municipality of Dibombari (AGRISTAT-MINADER 2010 data). 

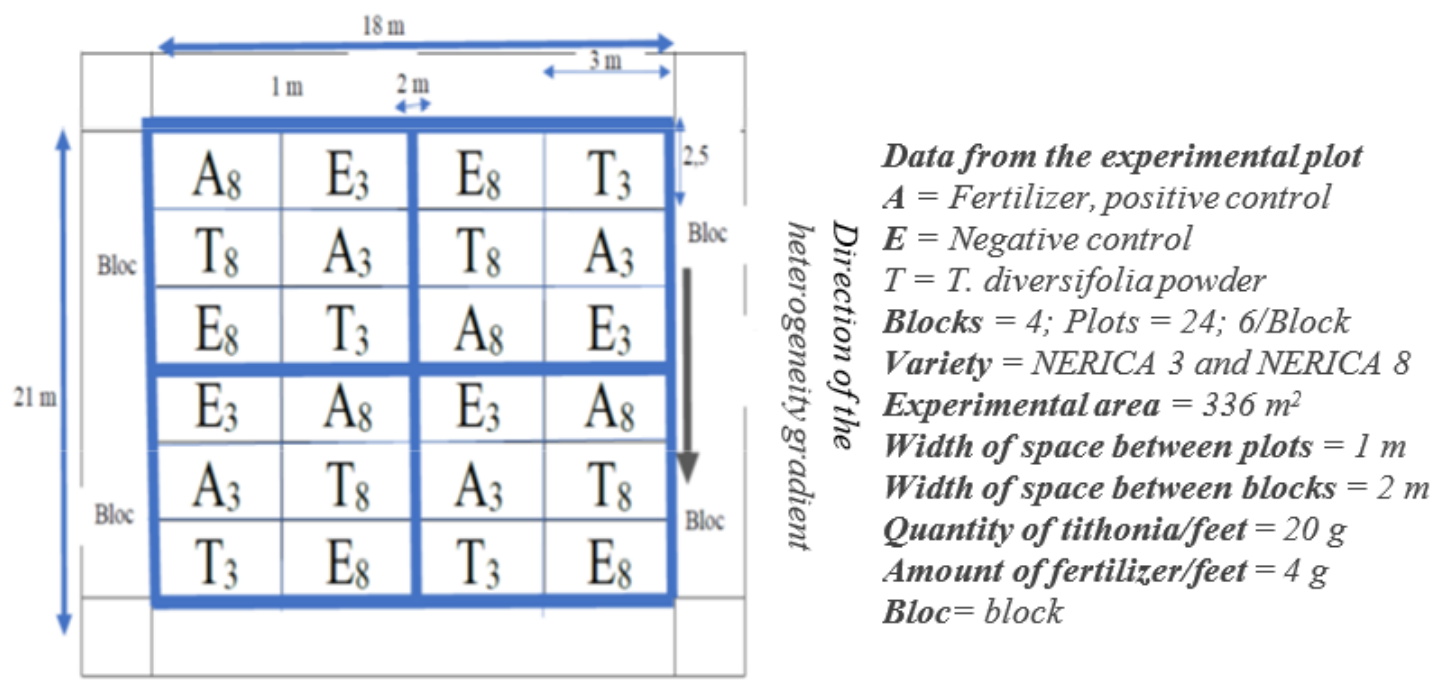

Fig. 3: Experimental design (Dagnelie, 2012).

\section{Field data collection}

The data were collected in a meter square of each plot; data were recorded on emergence, this was done by a complete count of the total number of plants emerged after two weeks after sowing; the appearance of the plants after emergence was evaluated after month of sowing on a scale of 1 to 5 ( 1 = weak vigor, $2-3=$ medium vigor, $4-5=$ vigorous plants); the vigor index of each concentration tested has been calculated by multiplying the germination rate (\%) and seedling length; The chlorophyll rate was took using chlorophyll-meter on the $45^{\text {th }}$ day after sowing; the number of tillers was noted on the $60^{\text {th }}$ day after sowing by an exhaustive count of the number of plants that contain $1 \mathrm{~m}^{2}$ in the middle of each plot, previously randomly marked during the assessment of emergence within the interior lines of each (25 plants $/ \mathrm{m}^{2}$ ) parcel; the disease index: the degree of infection of the plants was estimated by scores between $\mathrm{o}$ and 9 assigned after visual observation and inspired by the standard IRRI rice evaluation system (1980 and 1996). This rating reflected an average visual assessment of the density of lesions on the individual leaves. It was done on the $60^{\text {th }}, 80^{\text {th }}$ and $110^{\text {th }}$ day after sowing on a scale of 0 to 9: $0=$ no symptoms; $1-3=$ few symptoms (presence of brown spots about $1 \mathrm{~mm}$ in diameter); 4-6 = average presence of symptoms (less than $26 \%$ of the leaf area affected); 7-9 = high presence of symptoms (26 to $100 \%$ of the leaf area affected); at the end, production by elementary plot was obtained after harvest by weighing paddy rice from $1 \mathrm{~m}^{2}$ internal sowing lines_covering an area of $7.5 \mathrm{~m}^{2}$ (IRRI, 1980 and 1996).

\section{Yield estimation}

The harvest was carried out on the $110^{\text {th }} \pm 10$ days for the varieties used. For each elementary plot of 8 lines, only middle lines were collected in the area of $1 \mathrm{~m}^{2}$. The product of each plot was packed in a polyethylene bag. For each treatment the seeds were dry, weighed and yield was estimated using the formula of Kamau et al. (2011).

Yield $\left(\mathrm{t} \mathrm{ha}^{-1}\right)=$ weight $\left(\mathrm{kg} / \mathrm{m}^{2}\right) \times 10000 \mathrm{~m}^{2} / \mathrm{ha} \times 1 \mathrm{t} / 1000 \mathrm{~kg}$.

\section{Statistical analysis of data}

The data were subjected to analysis of variance (ANOVA) and the separation of means with the smallest significant difference (LSD), $p<0.05$, performed using the program SPSS 16.0 software.

\section{Results}

\section{Soil analysis from the two experimental sites}

The soils of Lelem site are a bit basic and suitable for the production of many crops because the optimal $\mathrm{pH}$ is located at an average between 7.00 and 8.00. The assimilable phosphorus contents are high as well as the base saturation rates. As the soil is not very basic, a drop in control is, therefore, necessary 
on these soils. Nitrogen and organic matter contents are also significant. An organic amendment in the form of chicken droppings is necessary, with an addition of nitrogen because the organic matter, although significant is less important because of its relatively significant $\mathrm{C} / \mathrm{N}$ ratio for all soils (Table 1).

The soil of Kompina site is very acidic $(\mathrm{pH}$ is located at an average between 5.3 and 5.2) and marginal for the production of any crop because the optimal $\mathrm{pH}$ of many crops is located at an average of 7.0. Consequently, the assimilable phosphorus contents are low as well as the base saturation rates. An increase in $\mathrm{pH}$ is, therefore, necessary on these soils with the addition of phosphorus. Nitrogen and organic matter contents are also low. An organic amendment in the form of chicken droppings is necessary, with an addition of nitrogen because the organic matter, although low is of poor quality because of its very high $\mathrm{C} / \mathrm{N}$ ratio for all soils (Table 2 ).

Table 1. Lelem soil analytical sheet.

\begin{tabular}{|c|c|c|c|c|c|}
\hline$\overline{\mathbf{N}^{\circ}}$ & $\overline{1}$ & 2 & 3 & 4 & 5 \\
\hline Codes & Lelem 1 & Lelem 2 & Lelem 3 & Lelem 4 & Lelem 5 \\
\hline \multicolumn{6}{|l|}{ Texture (\%) } \\
\hline Sand & 14 & 15 & 10 & 15 & 13 \\
\hline Silt & 50 & 54 & 54 & 52 & 52 \\
\hline Clay & 36 & 31 & 36 & 33 & 35 \\
\hline Textural class & LAS & LAS & LAS & LAS & LAS \\
\hline Coarse items (\%) & 0 & o & o & o & O \\
\hline \multicolumn{6}{|l|}{ Soil reaction } \\
\hline pH water & 7.5 & 6.8 & 7.1 & $7 \cdot 5$ & 7.9 \\
\hline $\mathrm{pH} \mathrm{KCl}$ & 8.0 & $7 \cdot 5$ & 8.0 & 8.0 & 8.8 \\
\hline$\Delta \mathrm{pH}$ & 0.5 & 0.7 & 0.9 & 0.5 & 0.9 \\
\hline \multicolumn{6}{|l|}{ Organic Matter } \\
\hline $\mathrm{CO}(\%)$ & 31.00 & 35.00 & 36.00 & 34.00 & 33.00 \\
\hline MO (\%) & 61.00 & 70.00 & 72.00 & 68.00 & 66.00 \\
\hline $\mathrm{N}(\mathrm{g} / \mathrm{kg})$ & 2.15 & 2.60 & 3.70 & 2.80 & 2.90 \\
\hline $\mathrm{C} / \mathrm{N}$ & 16.41 & 15.46 & 16.00 & 15.14 & 16.37 \\
\hline \multicolumn{6}{|c|}{ Exchangeable cations and acidity (meq/100 g) } \\
\hline $\mathrm{Ca}$ & 3.32 & 2.52 & 3.25 & 2.50 & 2.40 \\
\hline $\mathrm{Mg}$ & 80.00 & 79.00 & 77.00 & 76.00 & 76.00 \\
\hline $\mathrm{K}$ & 37.20 & 38.15 & 38.25 & 39.10 & 37.15 \\
\hline $\mathrm{Na}$ & 1.03 & 1.04 & 1.08 & 1.04 & 1.03 \\
\hline $\mathrm{S}$ & 2.91 & 3.16 & 4.20 & 3.08 & 2.92 \\
\hline $\mathrm{AE}$ & 2.12 & 2.08 & 2.10 & 2.19 & 2.12 \\
\hline \multicolumn{6}{|c|}{ Cation exchange capacity (meq/10o g) } \\
\hline CEC & 2190 & 21.82 & 21.48 & 21.50 & 21.56 \\
\hline CECE & 5.03 & 4.24 & $4 \cdot 30$ & 4.17 & 3.04 \\
\hline \multirow{2}{*}{\multicolumn{6}{|c|}{ Assimilable phosphorus (mg/kg) }} \\
\hline & & & & & \\
\hline P (Bray II) & 16.00 & 18.50 & 19.80 & 19.15 & 17.39 \\
\hline
\end{tabular}

\section{Chemical analyses of Tithonia diversifolia leaf powders}

The powder of $T$. diversifolia is basic $(\mathrm{pH} 9.1)$ and knowing that the optimal $\mathrm{pH}$ of the majority of culture is located at an average of 7.0, its application like any other chemical fertilizer must require a study of the soil. The powder of T. diversifolia contains phosphorus, nitrogen, and potassium in relatively small proportions. Note that $T$. diversifolia is very rich in potassium (7.3\%) compared to phosphorus (0.6\%) and nitrogen (4.4\%) (Table 3).

\section{Obtaining Tithonia diversifolia powder}

The powder of the leaves of $T$. diversifolia was obtained after drying and grinding of the dry plant material obtained. From $300 \mathrm{~kg}$ of fresh T. diversifolia material, we obtained $50 \mathrm{~kg}$ of powders which corresponds to a yield of $16.66 \%$. Low yield of less than $50 \%$. 
Table 2. Analytical sheet of Kompina soils.

\begin{tabular}{|c|c|c|c|c|c|}
\hline $\mathbf{N}^{\circ}$ & $\mathbf{1}$ & 2 & 3 & 4 & 5 \\
\hline Code & Kompina 1 & Kompina 2 & Kompina 3 & Kompina 4 & Kompina 5 \\
\hline \multicolumn{6}{|l|}{ Texture (\%) } \\
\hline Sand & 74 & 75 & 73 & 75 & 73 \\
\hline Silt & 06 & 07 & 06 & 07 & 06 \\
\hline Clay & 20 & 17 & 19 & 18 & 21 \\
\hline Textural Class & AS & AS & $\widehat{A S}$ & AS & AS \\
\hline Coarse items (\%) & o & o & o & o & 0 \\
\hline \multicolumn{6}{|l|}{ Soil reaction } \\
\hline $\mathrm{pH}$ water & 5.0 & $5 \cdot 3$ & 5.2 & 5.2 & 5.0 \\
\hline $\mathrm{pH} \mathrm{KCl}$ & 4.3 & 4.3 & 4.4 & 4.5 & 4.2 \\
\hline$\Delta \mathrm{pH}$ & -0.7 & -1.0 & -0.8 & -0.7 & -0.8 \\
\hline \multicolumn{6}{|l|}{ Organic Matter } \\
\hline $\mathrm{CO}(\%)$ & 1.54 & 1.07 & 1.92 & 1.65 & 1.10 \\
\hline OM (\%) & 2.65 & 1.84 & $3 \cdot 31$ & 2.84 & 1.90 \\
\hline $\mathrm{N}(\mathrm{g} / \mathrm{kg})$ & 0.30 & 0,26 & 0.41 & 0.36 & 0.28 \\
\hline $\mathrm{C} / \mathrm{N}$ & 51 & 41 & 47 & 46 & 40 \\
\hline \multicolumn{6}{|c|}{ Exchangeable cations and acidity (meq/100 g) } \\
\hline $\mathrm{Ca}$ & 1.32 & 1.52 & 2.25 & 1.50 & 1.40 \\
\hline $\mathrm{Mg}$ & 0.36 & 0.45 & 0.62 & 0.44 & 0.34 \\
\hline $\mathrm{K}$ & 0.20 & 0.15 & 0.25 & 0.10 & 0.15 \\
\hline $\mathrm{Na}$ & 0.03 & 0.04 & 0.08 & 0.04 & 0.03 \\
\hline $\mathrm{S}$ & 1.91 & 2.16 & 3.20 & 2.08 & 1.92 \\
\hline $\mathrm{AE}$ & 0.12 & 0.08 & 0.10 & 0.09 & 0.12 \\
\hline \multicolumn{6}{|c|}{ Cation exchange capacity (meq/100 g) } \\
\hline $\mathrm{CEC}$ & 17.90 & 19.82 & 20.48 & 20.50 & $17 \cdot 56$ \\
\hline CECE & 2.03 & 2.24 & $3 \cdot 30$ & 2.17 & 2.04 \\
\hline $\mathrm{V}$ & 11 & 11 & 16 & 10 & 11 \\
\hline \multicolumn{6}{|c|}{ Assimilable phosphorus (mg/kg) } \\
\hline P (Bray II) & 8.00 & 13.50 & 7.82 & 10.15 & 8.39 \\
\hline
\end{tabular}

Table 3. Chemical composition of powdered leaves of T. diversifolia.

\begin{tabular}{lll}
\hline $\mathbf{N}^{\mathbf{0}}$ & Elements analyzed & Experimental values \\
\hline 1 & pHwater & 9.1 \\
2 & pHKCl & 8.5 \\
4 & pHwater/pHKCl & 1.1 \\
3 & Nitrogen (\%) & 4.4 \\
4 & Phosphorus (\%) & 0.6 \\
5 & Potassium (\%) & 7.3 \\
\hline
\end{tabular}

\section{Phytochemical screening}

The results of phytochemical screening have shown that the leaves of $T$. diversifolia are rich in phenols, flavonoids, tannins, lipids, saponins, anthocyanins, and alkaloids.

\section{Extraction of essential oils of $T$. diversifolia}

The yield finally obtained from hydrodistillation is $6 \%$. The organoleptic characteristics obtained by the panel show that the colors of the essential oils go from light yellow to $T$. diversifolia, whereas the flavors are sweet and pungent.

\section{Growth parameters and yield}

For field work, the results of antimicrobial activities have shown that only essential oils were more effective than aqueous extracts of the leaves of $T$. diversifolia against pathogens in rice seeds. Then the extract of essential oil of $T$. diversifolia was used for the treatment of rice seeds by coating the seeds for $30 \mathrm{~min}$, then for field work leave 24 hours at room temperature before sowing. the leaf powders of $T$. diversifolia were used as fertilizer by soil amendment. The tables below (Tables 4 and 5) show the results of the production characteristics in the field. 
Table 4. Emergence, Appearance of plants, tillering, disease index and production of two cultivars of rice seeds treated with essential oil and amendment by T. diversifolia powders in Lelem locality.

\begin{tabular}{|c|c|c|c|c|c|c|c|c|}
\hline Treatments & $\begin{array}{l}\text { Emergence } \\
(\%)\end{array}$ & $\begin{array}{l}\text { Seedling } \\
\text { appearance }\end{array}$ & Tillering & $\begin{array}{l}\text { Sizes } \\
(\mathrm{cm})\end{array}$ & Vigor & $\begin{array}{l}\text { Illness } \\
\text { index }\end{array}$ & $\begin{array}{l}\text { Weight per } \\
\text { plots (kg) }\end{array}$ & Yield (tha-1) \\
\hline \multicolumn{9}{|l|}{ Powder } \\
\hline N3 & $98.0 \pm 2.0$ & $4.7 \pm 0.6$ & $37 \cdot 3 \pm 1,5$ & $158.3^{*} \pm 1.5$ & $232750^{*} \pm 5.0$ & $0.7 \pm 0.6$ & $4.0 \pm 0.1$ & $1.3^{*} \pm 0.1$ \\
\hline N8 & $96.0 \pm 4.0$ & $4.7 \pm 0.6$ & $37.3 \pm 2.5$ & $158.6^{*} \pm 1.2$ & $227686.6^{*} \pm 9.0$ & $0.0 \pm 0.0$ & $11 \pm 0.1$ & $3.7^{*} \pm 0.2$ \\
\hline \multicolumn{9}{|l|}{ Fertilizer } \\
\hline N3 & $94.7 \pm 4.0$ & $4.7 \pm 0.6$ & $38.3^{*} \pm 1.5$ & $160.3^{*} \pm 0.6$ & $227673.3^{*} \pm 1.9$ & $0.3 \pm 0.6$ & $6.0 \pm 0.1$ & $2.0^{*} \pm 0.6$ \\
\hline N8 & $97.0 \pm 2.6$ & $4.7 \pm 0.6$ & $39.3^{*} \pm 0.6$ & $160.0^{*} \pm 1.0$ & $232800^{*} \pm 2.2$ & $0.3 \pm 0.6$ & $10.5 \pm 0.1$ & $3.5^{*} \pm 0.2$ \\
\hline \multicolumn{9}{|l|}{ Control } \\
\hline N3 & $91.3 \pm 1.2$ & $4.0 \pm 0.0$ & $29.0 \pm 1.0$ & $150.6 \pm 0.6$ & $206413.3 \pm 0.5$ & $3.4 \pm 0.6$ & $3.0 \pm 0.1$ & $1.0 \pm 0.1$ \\
\hline N8 & $95.3 \pm 5.0$ & $4.3 \pm 0.6$ & $29.6 \pm 0.6$ & $150.0 \pm 1.0$ & $214500 \pm 4.5$ & $1.2 \pm 0.6$ & $5.0 \pm 0.1$ & $1.7 \pm 0.1$ \\
\hline
\end{tabular}

The data in the Table are the means \pm SD of four repetitions over an area of $7.5 \mathrm{~m}^{2} .{ }^{*}$ : Denotes the statistically significant difference (P<0.05) between treatments and untreated control with a superior treatment.

Table 5. Emergence, Appearance of plants, tillering, disease index and the production of two cultivars of rice seeds treated with essential oil and amendment by powders of T. diversifolia in Kompina locality.

\begin{tabular}{|c|c|c|c|c|c|c|c|c|}
\hline Treatments & $\begin{array}{l}\text { Emergence } \\
\text { (\%) }\end{array}$ & $\begin{array}{l}\text { Seedling } \\
\text { appearance }\end{array}$ & Tillering & $\begin{array}{l}\text { Sizes } \\
(\mathrm{cm})\end{array}$ & Vigor & $\begin{array}{l}\text { Index } \\
\text { diseases }\end{array}$ & $\begin{array}{l}\text { Weight per } \\
\text { plots (kg) }\end{array}$ & Yield (tha-1) \\
\hline \multicolumn{9}{|l|}{ Powder } \\
\hline N3 & $94.0 \pm 0.0$ & $4.7 \pm 0.6$ & $30.3 \pm 1.5$ & $100.3^{*} \pm 1.5$ & $9428.2 \pm 5.0$ & $1.6 \pm 0.6$ & $4.0 \pm 0.1$ & $1.3^{*} \pm 0.2$ \\
\hline N8 & $94.0 \pm 0.0$ & $4.7 \pm 0.6$ & $30.3 \pm 2.5$ & $100.6^{*} \pm 1.2$ & $9456.4 \pm 9$ & $0.0 \pm 0.0$ & $8.0 \pm 0.1$ & $2.7^{*} \pm 0.6$ \\
\hline \multicolumn{9}{|l|}{ Fertilizer } \\
\hline N3 & $92.0 \pm 0.0$ & $4.7 \pm 0.6$ & $32.3^{*} \pm 1.5$ & $100.3^{*} \pm 0.6$ & $9227.6 \pm 1.9$ & $1.3 \pm 0.6$ & $4.0 \pm 0.1$ & $1.3^{*} \pm 0.1$ \\
\hline N8 & $92.0 \pm 0.0$ & $4.7 \pm 0.6$ & $32.3^{*} \pm 0.6$ & $100.0^{*} \pm 1$ & $9200.0 \pm 2.2$ & $1.3 \pm 0.6$ & $8.5 \pm 0.1$ & $2.8 * \pm 0.5$ \\
\hline \multicolumn{9}{|l|}{ Control } \\
\hline N3 & $90.0 \pm 0.0$ & $4.0 \pm 0.0$ & $29.0 \pm 1.0$ & $100.6 \pm 0.6$ & $9054.0 \pm 0.5$ & $1.4 \pm 0.6$ & $3.0 \pm 0.1$ & $1.0 \pm 0.2$ \\
\hline N8 & $92.0 \pm 0.0$ & $4.3 \pm 0.6$ & $29.7 \pm 0.6$ & $100.0 \pm 1$ & $9200.0 \pm 4.5$ & $1.2 \pm 0.6$ & $4.0 \pm 0.1$ & $1.3 \pm 0.3$ \\
\hline
\end{tabular}

The data in the table are the means \pm SD of four repetitions over an area of $7.5 \mathrm{~m}^{2}$. * : Denotes the statistically significant difference $(P<0.05)$ between treatments and untreated control with a superior treatment. 


\section{Growth parameters and yield in Lelem site}

Impact of treatments of rice seeds with essential oil and amendment with $T$. diversifolia powders on emergence, the appearance of plants, degree of tillering, disease index, and yield in the locality from Lelem are represented in Table 4. It observed that the powder and essential oil increase the yield compare to control (Table 4).

\section{Growth parameters and yield in Kompina site}

Impact of treatments of rice seeds with essential oil and amendment with $T$. diversifolia powders on emergence, the appearance of plants, degree of tillering, disease index and yield in the locality of Kompina are represented in Table 5. It observed that the powder and essential oil increase vigor and yield compare to control (Table 5).

It appears from his two tables (Tables 4 and 5) that Emergence and Aspect of plants are very important for both sites. In the Lelem site (Table 4), the plots with plants amended to the powder of $T$. diversifolia had a great vigor compared to the negative control. In the Kompina site, the plots had almost the same vigor. In the Lelem site, tillering and size were very important and the maximum tillering average was 39 and the maximum mean size was between $150-65 \mathrm{~cm}$.

The largest tillering and size were obtained in the almond plots with $T$. diversifolia powders compared to the untreated ones. While in the site of Kompina the tillering and the size decreased considerably and without significant difference for each treatment. In the Lelem site, the Disease Index was negligible. No symptoms of the seedborne diseases were noted such as Helminthosporiosis and fusariosis. The plants were very vigorous and the climate was very favorable for normal development. In contrast, at the Kompina site, the Disease Index was between 1-2 on the scale based on the standard IRRI rice rating system (1980 and 1996).

The plants were not very vigorous and the climate was not very favourable for the normal development of the plants. We noted some attacks of the plants and also of the paddy produced (Fig. 4). In the Lelem site, Production (per elementary plot in $\mathrm{kg}$ ) and the yield per experimental plot were very high in the plots amended with $T$. diversifolia powders compared to the unamended control (Table 4); whereas in the Kompina site, Production (per elementary plot in $\mathrm{kg}$ ) and the yield per experimental plot were also high in the plots amended with $T$. diversifolia powders compared to the unamended control (Table 5). However, this production was very high at the Lelem site than at the Kompina site. This low production at the Kompina site could be explained by the presence of different climates at the two experimental sites.

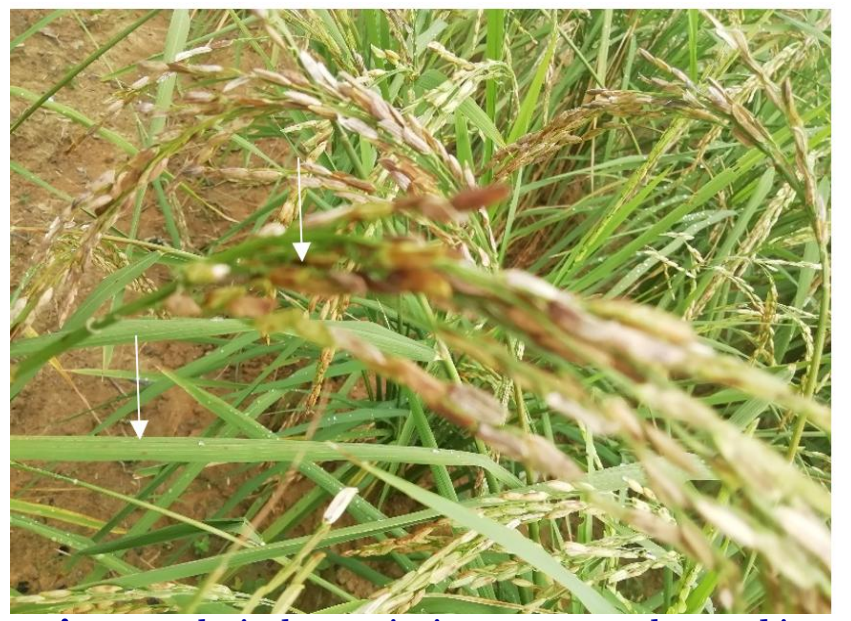

Fig. 4. Helminthosporiosis symptoms observed in Kompina site.

\section{Weight of 1000 grain}

The average weight of 1000 seeds of the two different sites is shown in the table 6 below. The plots amended with chemical fertilizer and powder $T$. diversifolia had a higher weight than the untreated plots. The average weight of 1000 seeds was relatively high in Lelem site than in the Kompina site (Table 6).

\section{Variation of chlorophyll rate}

Table 7 represents the chlorophyll rate of each treatment in the two different sites. From this table, the chlorophyll rate is very high in the plots treated with fertilizer and powder of T. diversifolia than in the untreated plots. The chlorophyll rate is very high in Lelem site than in the Kompina site (Table 7). 
Table 6. The weight of 1000 seeds of each treatment.

\begin{tabular}{lllllll}
\hline Treatments & \multicolumn{1}{l}{ Powder of $\boldsymbol{T}$. diversifolia } & Fertilizer & \multicolumn{3}{c}{ Control } \\
\hline Varieties & $\mathrm{N} 3$ & $\mathrm{~N} 8$ & $\mathrm{~N} 3$ & $\mathrm{~N} 8$ & $\mathrm{~N} 3$ & $\mathrm{~N} 8$ \\
Weight (g) in Lelem site & $33 \pm 0.2$ & $32 \pm 0.1$ & $31 \pm 0.1$ & $33 \pm 0.2$ & $29 \pm 0.1$ & $29 \pm 0.1$ \\
Weight (g) in Kompina site & $30 \pm 0.1$ & $31 \pm 0.0$ & $31 \pm 0.00$ & $30 \pm 0.1$ & $29 \pm 0.1$ & $29 \pm 0.0$ \\
\hline
\end{tabular}

The data in Table 6 are the mean \pm SD of four replicates.

Table 7. Chlorophyll variation rate for each treatment.

\begin{tabular}{lllllll}
\hline \multicolumn{2}{l}{ Treatments } & Powder of $\boldsymbol{T}$. diversifolia & Fertilizer & \multicolumn{3}{c}{ Control } \\
\hline Varieties & $\mathrm{N} 3$ & $\mathrm{~N} 8$ & $\mathrm{~N} 3$ & $\mathrm{~N} 8$ & $\mathrm{~N} 3$ & $\mathrm{~N} 8$ \\
Chlorophyll in Lelem site & $34 \pm 0.7$ & $36 \pm 0.5$ & $35 \pm 1.2$ & $36 \pm 1.0$ & $27 \pm 0.6$ & $26 \pm 0.4$ \\
Chlorophyll in Kompina site & $26 \pm 0.2$ & $25 \pm 0.1$ & $27 \pm 0.2$ & $26 \pm 0.3$ & $23 \pm 0.1$ & $24 \pm 0.4$ \\
\hline
\end{tabular}

The data in Table 7 are the mean \pm SD of four replicates.

\section{Discussion}

The treatment of seeds with essential oil and the amendment of the soil with the powder of leaves of $T$. diversifolia improved the various parameters in the field such as the emergence, chlorophyll rate, the appearance of the plants, the degree tillering, disease index and production. Significant differences in the density of the plants and the degree of tillering had repercussions in the same order of magnitude on the production except in the case of control without amendment. The synthetic fertilizer stimulated the emergence and tillering of the plants after the amendment. Powder of T. diversifolia has shown the best effect with a slight superiority to synthetic fertilizer. This similarity and superiority of this fertilizing form of $T$. diversifolia compared to synthetic fertilizer could be attributed to their content in active elements and compounds and to their great stability. This result confirms the effect of essential oil on the pathogens of rice seeds. According to the previous work, the chemical analysis of this oil, by Gas Chromatography, shows that it is rich in phenolic compounds and terpenoids. These compounds have strong antimicrobial power (Hulin et al., 1998; Nyegue et al., 2014). Phytochemical screening also shows that $T$. diversifolia powder is rich in polyphenols, terpenoids, alkaloids, saponins, lipids, and tannins with very important biological activities (Yoon et al., 2010), hence the considerable reduction of the symptoms of seed-borne diseases in the field. The results obtained in the field correlated the observations under laboratory conditions.

Concerning the total harvest weights and the weight of 1000 seeds, the amendments which gave the best harvest results are those amended to $T$. diversifolia powder and synthetic fertilizer on the two cultivars. Regarding only NERICA 8, their harvest represents $41.5 \%$ and $39.6 \%$, respectively of the total weight of the harvest. Harvest is high compare to control no amended which represents $18.9 \%$ of the total weight of the harvest. These results can be justified by the fact that $T$. diversifolia powder is rich in fertilizing elements such as Nitrogen (N), Phosphorus (P) and Potassium (K) from which their origin comes either from the soil or from nutrients provided. Compared to the control plots where the only source of nutrients in the soil. Its elements go into synthesis and production in the plant. The richness in these nutrients in these treated plots may also explain why the plants in these plots were vigorous, with a high chlorophyll content compared to the untreated plots. Besides, fertilization is one of the most important factors that affect crop yield and plant health (Nawal et al., 2014).

Mengel and Kirkby (1982) indicated that nitrogen is an essential element for plant growth. Lafon et al. (1985) reported that the mineral nitrogen absorbed by the plant is used for the synthesis of amino acids, and plays a very important role in growth. Nitrogen is also a fundamental element of plant tissue, it enters the formula of many constituents of structure (proteins), function (enzyme and coenzymes) and reserves (many grains). Nitrogen plays a role in the development of the vegetative apparatus (foliage), the place of synthesis of carbohydrates by the phenomenon of photosynthesis (Mehari, 1997). For the production of cereals and in the case of rice, $2 / 3$ of the nitrogen absorbed by the plant is supplied by the soil (Russo, 1996). Phosphorus is also an essential element for plant life. Of the three major 
elements, phosphorus is recognized as having an effect on root growth, this shows the importance of localized phosphate manure, or rich soil on the rapid growth of plants. A good supply of phosphorus for the root system is necessary (Ben Tassil, 1981). Potassium is a major element essential for plant growth, its main functions in the plant are photosynthesis and translocation (assimilates, opening and closing of stomata and enzyme activation) (Mengel and Kirkby, 1982). The major nutrient requirements for the rice plant are known (Brown, 1993). The fertilizer formula used varies from one rice farmer to another, depending on the nature of the soil and the previous crop (Hsieh, 1992).

Regarding production, it was very high at the Lelem site than at the Kompina site despite the amendment. This low production at the Kompina site can hardly be explained by the presence of a very hot climate compared to that of Lelem, which is less hot. The season could also be one of the factors determining production, in the Lelem site, cultivation was carried out in the first rainy season (March-July) characterised by a high quantity of water, on the other hand, in the Kompina zone, cultivation was carried out in the second rainy season (September-November) characterised by a low quantity of water. Also the soil could also have a very great influence on this production. According to analyses, the soil of Kompina is very acidic compared to the soil of Lelem which is a little basic. Also, the $\mathrm{C} / \mathrm{N}$ ratio is very high $(\mathrm{C} / \mathrm{N}>40 \%)$ in the Kompina experimental site than in the Lelem site $(\mathrm{C} / \mathrm{N}<15 \%)$. This means that in the Lelem site, organic matter is more bioavailable to the plant than in the Kompina site. According to N'Dayegamiye et al. (2005) when the ratio $\mathrm{C} / \mathrm{N}$ is low, the quantity of organic matter is bioavailable. In addition, the content of $\mathrm{Mg}, \mathrm{N}, \mathrm{P}, \mathrm{K}$ is high in the Lelem site, which results in good photosynthesis and good production.

These results make it possible to recommend the use of the essential oil of $T$. diversifolia as a biopesticide and the powder $T$. diversifolia as a biofertilizer to control rice seeds to improve the quality and quantity of rice produced in Cameroon, where farmers are limited resources. Given the possibility of domesticating $T$. diversifolia on a large scale, their new users added to their use in traditional pharmacopeia and as flavorings in food would increase the income of farmers. However, an economic evaluation of such treatments would be appropriate to better understand their impacts.

\section{Conclusion}

At the end of this work, which focused on the evaluation in the field of seed treatments using the essential oil of $T$. diversifolia and the soil amendment using powders from the same plant, it shows that the treatments of the plots amended with the powder and seeds treated with essential oil from the same plant had a positive impact on the improvement of growth parameters and production yield; as well as reducing the incidence of the disease. These results were almost similar to the plots amended by fertilizer and seeds treated with essential oil from the same plant and superior to the results of untreated plots. We recorded a large production in the Lelem site than in the Kompina site. Given these results, it remains to explore this natural resource to produce a biofertilizer or a biopesticide. For this, we have soon to deeply characterize the powders of $T$. diversifolia and to test in several areas.

\section{Conflict of interest statement}

Authors declare that they have no conflict of interest.

\section{Acknowledgement}

The authors of this work thank the Laboratory of Phytopathology, Biological Science, and Plant Biology of University of Yaoundé 1, and University of Maroua, Cameroon.

\section{References}

Agarwal, P.C., Carmen Mortensen, N., Mathur, S. B., 1989. Seed-borne diseases and seed health testing of rice. Technical Bulletin No. 3 and Phytopathological Papers No. 30. Danish Government Institute of Seed Pathology for Developing Countries, Copenhagen, Denmark, and $\mathrm{CAB}$ International Mycological Institute, Kew, Surrey, United Kingdom. 106p.

Anonyme, 1983. United States Agency for International Development (USAID). Agriculture Sector Briefing Paper. 40p.

Anonyme, 1986. International Fertilizer 
Development Center/ USAID. Cameroon fretilizer sector study. 14p.

Anonyme, 1988. NCRE Annual report. USAIDIRAD-IITA. 286p.

Ben Tassil, A., 1981. Contribution to the study of rooting and absorption of phosphorus and potassium in sugar beet and corn. Master's thesis Agronomy IAV Hassan II, Rabat.

Bengyella, L., Sayanika, D. W., Pranab, R., Pardeep, K. B., Mohendro, W. S., Sharma, K. C., Narayan, C. T., 2011. Invasion of Solanum tuberosum L. by Aspergillus terreus: a microscopic and proteomics insight on pathogenicity. BMC Res. Notes. 7(1), 35op.

Brown, Ph., 1993. Fertilization in the Camargue. Agric. Outlook. 183, 21-23.

Bruneton, J., 1999. Pharmacognosy, Phytochemistry, Medicinal plants. $3^{\text {rd }}$ Edn. Tec and Doc. Lavoisier, Paris.

Dagnelie, P., 2012. Principles of experimentation: planning of experiments and analysis of their results. Electronic edition, <www.dagnelie.be>, 413p.

Edeoga, H., Okwo, D., Mbaebie, B., 2005. Phytochemical constituents of Nigerian medicinal plants. Afr. J. Biotechnol. 4, 685-688.

FAOSTAT, 2019. Food and Agriculture Organisation of the United Nations Database. Main series of world statistics. Available online at htt://apps.fao.org/.

Fouelefack, F. R., Nguefack, J., Dongmo, L. J. B., Dongmo, N. A., Azah, U. R., Nkengfack, A. E., 2018. Effects of extracts of Oxalis barrelieri L. and Cymbopogon citratus Stapf, coupled with $\mathrm{NaCl}$ sorting on seed health, germination, and seedlings vigor of rice (Oryzae sativa L). Afr. J. Agric. Res. 13 (3), 104-114.

Guilter, H. G., 1998. Biologically Active Natural Products: Potential Use in Agriculture. American Chemical Sociaty, Washington: 1-2.

Harbone, J. B., 1976. Phytochemical Methods. A Guide of Modern Techniques of Plant Analysis. Chapman and Hall, London (England). 150p.

Harish, S., Saravanakumar, D., Radjacommare, R., Ebenezer, E. G., Seetharaman, K., 2008. Use of plant extracts and biocontrol agents for the management of brown spot disease in rice. BioControl. 53, 555-567.

Hsieh, C. F., 1992. Nutrition management of food crops in proceeding of the workshop on paddy rice and upland crops production. Taitchung District Agricultural Improvement Station. The
Republic of China.

Hulin, V., Mathot, A. G., Mafart, P., Dufossé, L., 1998. Antimicrobial properties of essential oil and aromatic compounds. Food Sci. 18, 563582.

Institut National de la Statistique/MINADER/ DESA, 2010 and 2017. Annuaire Statistique du Cameroun, chapitre $13,13^{\mathrm{e}}$ édition.

International Rice Research Institute (IRRI), 1980. IRRI Standard Evaluation System for rice. Los Banos (Philippines), 196p.

International Rice Research Institute (IRRI), 1996. The Standard Evaluation System for Rice, INGER, Genetic Resources Centre International, Rice Research Institute, Philippine, (4 ${ }^{\text {th }}$ Edn.), 52p.

Kagale, S., Marimuthu, T., Thayumanavan, B., Nandakumar, R., Samiyappan, R., 2004. Antimicrobial activity and induction of systemic resistance in rice by leaf extract of Datura metel against Rhizoctonia solani and Xanthomonas oryzae pv. oryzae. Physiol. Mol. Plant Pathol. 65, 91-100.

Kaho, F., Nyambi Na-ah, G., Yemefack, M., Yongue-Fouateu, R., Amang-Abang, J., Bilong P., Tonyé, J., 2009. Screening of seven plant species for short term improved fallow in the humid forest zone of Cameroon. Commun. Soil Sci. Plant Anal. 40, 1-10.

Kamau, J., Melis, R., Laing, M., Derera, J., Shanahan, P., Ngugi, C. K. E., 2011. Farmers' participatory selection for early Bulking Cassava genotypes in semi-arid Eastern Kenya. J. Plant Breed. Crop Sci. 3(3), 44-52.

Kohls, C. L., Percich, J. A., 1987. Wild rice losses associated with growth-stage-specific fungal brown spot epidemics. Plant Dis. 71, 419-422.

Lafon, J. P., Prayer, C. T., Levy, G., 1985. Biology of Cultivated Plants. Volume I. Organization of the Physiology of Nutrition, Edition of the A.R.P.E.P.S Anger, pp.166-180.

Linthoingambi, W., Muthum S. S., 2013. Antimicrobial activities of different solvent extracts of Tithonia diversifolia (Hemsely) A. Gray. Asian J. Plant Sci. Res. 3(5), 50-54.

Mehari, A. H., 1997. Diagnosis of the fertility of soils planted with sugar cane in the perimeter of Gharb. Dissertation of DESA, IBN Tofail University, Faculty of Science, Kenitra, Morocco, 6op.

Mengel, K., Kirkby, A., 1982. Principles of Plant Nutrition. International Potash Institute, 655p.

N. A. Dongmo et al. (2020) / Effect of essential oil and powders of Tithonia diversifolia on the growth parameters and yield of rice in the field 
Mondingo, E. J., 2007. Situation of the forests in Cameroon. Cameroon Wild Life Society Conservetion, 24p.

N’Dayegamiye, A., Turcot, M., Laverdière, M. R., 2005. Effects of composted urban residues on corn yields and on some soil properties changes. Agrosol. 16(1), 91-99.

Nawal, I., Abdellatif, O. C., Mohamed, C., Jihane, T., Amina, O. T., Rachid, B., Allal, D., 2014. Effect of fertilization by different levels of N PK on the development of rice leaf diseases. J. Anim. Plant Sci. 23(1), 3601-3625.

Nguefack, J., Somda, I., Motensen, C. N., Amvam Zollo, P. H., 2005. Evaluation of five essential oils from aromatic plants of Cameroon for controlling seed-borne bacteria of rice (Oryza sativa L.). Seed Sci. Technol. 33, 397407.

Pauwels, J., Van Ranst, E., Verloo, M., Mvondo, Z. E. A., 1992. Manual of Soil Laboratory,
Methods of Soil and Plant Analysis: Equipment and Inventory Management for Glassware and Chemicals. Agricultural Publications $\mathrm{n}^{\circ}$ 28, A. G. C. D. Brussels, Belgium, 180p.

Russo, S., 1996. Rice yield as affected by the split method of "N" application and nitrification inhibitor DCD in Chataigner. Agronomic perspectives of rice cultivation in the Mediterranean. Water and fertilizer Consumption. CIHEAM. 5, 43-52.

Sarla, N., Mallikarjuna Swamy, B. P., 2005. Oryza glaberrima: A source for the improvement of Oryza sativa. Curr. Sci. 89(6), 955-963.

Sehgal, D. K., 2012. Split Plot and Strip Plot designs. IASRI, Library Avenue, New Delhi. pp.377-388.

Yoon, J. I., Al-Reza, S. M., Kang, S. C., 2010. Hair growth promoting effect of Zizyphus jujuba essential oil. Food Chem. Toxicol. 48, 13501354 .

\section{How to cite this article:}

Dongmo, N. A., Nguefack, J., Fouelefack F. R., Dakolé, D. C., Kuate, T. W. N., Nkengfack, A. E., Dongmo, L. J. B., 2020. Effect of essential oil and powders of Tithonia diversifolia on the growth parameters and yield of rice in the field. Int. J. Curr. Res. Biosci. Plant Biol. 7(1), 33-45.

doi: https://doi.org/10.20546/ijcrbp.2020.701.004 